\title{
Estimation of Serum Homocysteine: As a Diagnostic Marker of Oral Sub Mucous Fibrosis
}

\author{
Deepak Narang ${ }^{1}$, Shamma Shishodiya ${ }^{2}$, Jaideep Sur ${ }^{3}$ and Niyaz Fatma Khan ${ }^{4}$ \\ ${ }^{1}$ Senior Resident / Senior Lecturer Faculty, College of Dental Sciences and Research, Rungta, Bhillai, Chattisgarh, India \\ ${ }^{2}$ Diplomate national Board [DNB] Gangaram Medical college and Hospital Karol bagh, New Delhi, India \\ ${ }^{3}$ Post Graduate Faculty - @MDS[Reader] - Guide to Post graduate students, College of Dental Sciences and Research, Bhillai, Chattisgarh, India \\ ${ }^{4}$ Senior Resident / Senior Lecturer Faculty, College of Dental Sciences and Research, Bhillai, Chattisgarh, India
}

*Corresponding author: Deepak Narang, Senior Resident / Senior Lecturer Faculty [MDS @ORAL MEDICINE), College of Dental Sciences and Research, Rungta, Bhillai, Chattisgarh, India, Tel: 00915942248115; E-mail: parasitology1979@gmail.com

Received date: May 06, 2013, Accepted date: Sep 19, 2014, Published date: Sep 25, 2014

Copyright: ( 2014 Narang D, et al. This is an open-access article distributed under the terms of the Creative Commons Attribution License, which permits unrestricted use, distribution, and reproduction in any medium, provided the original author and source are credited.

\begin{abstract}
Oral sub mucous fibrosis is indeed one of the classic "Diseases of civilization" with large differences being seen between races, geographic areas and individuals at different levels in both prevalence and degree to which it transforms into malignancy with continuation of habit, with increased frequency and duration. In majority of cases oral cancers develop from pre-existing lesions and conditions which are mainly a result of carcinogenic agents like tobacco, lime, alcohol, betel nut, spices etc. Several studies in the past have tried to evaluate serum levels of homocysteine in oral squamous cell carcinoma but till date there is no documentation on serum Homocysteine levels in Oral Pre cancers. The present research was carried to find out if serum homocysteine can be used for the diagnosis of O.S.M.F.
\end{abstract}

Methodology: The research was conducted on $(n=50)$ patients suffering from the disease of O.S.M.F clinically and pathologically diagnosed not undergoing treatment.

Results: In our study serum homocysteine level was increased in all patients irrespective of gender and age. There was no statistically significant co-relation when comparing homocysteine level among clinical stages and pathological grading.

Conclusion: This is the first research to estimate serum homocysteine in OSMF which suggest that chronic inflammation in OSMF leads to hyperhomocysteinemia which could be used to assess the level of severity of disease and may be used as prognosticator for treatment of the disease.

Keywords: Oral submucous fibrosis; Homocysteine; Oxidative stress; Inflammation; NF-K $\beta$

\section{Introduction}

Oral sub mucous fibrosis is an insidious, chronic disease affecting any part of oral cavity and sometimes the pharynx. Although occasionally preceded by and or associated with vesicle formation, it is always associated with a juxtra-epithelial inflammatory reaction followed by a fibro-elastic change of the lamina propriety, with epithelial inflammatory reaction followed by fibro-elastic change of lamina propria, with epithelial atrophy, leading to stiffness of oral mucosa and causing trismus and inability to eat [1]. Homocystéine found in humans is a sulphur containing amino-acid formed during methionine metabolism in the methionine cycle. It can dimerise to Homocystéine or form disulphide bonds with proteins to form "protein-bound" homocysteine. In plasma $80 \%$ of homocysteine is protein bound. Homocystéine is a four carbon amino acid $[\mathrm{HS}(\mathrm{CH} 2) 2 \mathrm{CHNH} 2 \mathrm{COOH}]$ resulting from the demethylation of methionine. Homocysteine is a dimer composed of two oxidized molecule of Homocysteine linked by a disulphide bond [2].

\section{Material and Methods}

Chosen for evaluating homocysteine were $(n=50)$ patients suffering from disease of oral sub mucous fibrosis. Patients suffering from Cardiovascular disease, Osteoporosis, Dementia, Alzheimer's disease, Lung cancer, Oral cancer, Breast cancer and any other malignancy were excluded from the study.

\section{Results}

The mean value of serum Homocysteine found in males was 26.9 $\mu \mathrm{mol} / \mathrm{lts}( \pm 8.1)$ female was $21.4 \mu \mathrm{mol} / \mathrm{lts}( \pm 3.4)$ \& total $24.1 \mu \mathrm{mol} / \mathrm{lts}$ $( \pm 3.3)$ which showed that higher level of serum homocysteine found in OSMF patients and males had higher value than females (Table 1).

\begin{tabular}{|l|l|}
\hline Gender & Mean Homocysteine $(\mu \mathrm{mol} / \mathrm{lit})$ \\
\hline Males & $26.9( \pm 8.1)$ \\
\hline Females & $21.4( \pm 3.4)$ \\
\hline Total & $24.2( \pm 3.3)$ \\
\hline
\end{tabular}

Table 1: Mean serum homocysteine level in OSMF patients. 
Page 2 of 3

Mean Homocysteine level gradually increased from stage II to stage IV among males and females (p-value was 0.276 and 0.657 among males and females respectively which was found to be not significant) indicating that clinical progression is directly related to level of Homocysteine as the clinical stage of disease advances (Table 2).

\begin{tabular}{|l|l|l|l|l|l|l|}
\hline Gender & $\begin{array}{l}\text { Stage I } \\
\text { Mean } \pm \text { (S.D) }\end{array}$ & $\begin{array}{l}\text { Stage II } \\
\text { Mean } \pm \text { (S.D) }\end{array}$ & $\begin{array}{l}\text { Stage III } \\
\text { Mean } \pm \text { (S.D) }\end{array}$ & $\begin{array}{l}\text { Stage IV } \\
\text { Mean } \pm(\text { S.D) }\end{array}$ & F value & P Value \\
\hline Males & - & $25.88( \pm 7.84)$ & $26.98( \pm 8.67)$ & $32.93( \pm 5.41)$ & 1.326 & $0.276($ N.S $)$ \\
\hline Females & - & $20.35( \pm 4.17)$ & $0.0 \pm 0.0$ & $23.40( \pm 0.00)$ & 0.356 & $0.657($ N.S $)$ \\
\hline Total & - & $25.47( \pm 7.72)$ & $26.98( \pm 8.67)$ & $31.02( \pm 6.33)$ & 1.059 & $0.355($ N.S $)$ \\
\hline
\end{tabular}

Table 2: Comparison of mean values - Homocysteine ( $\mu \mathrm{mol} / \mathrm{lit})$ with clinical staging of OSMF.

\begin{tabular}{|l|l|l|l|l|l|l|}
\hline Gender & $\begin{array}{l}\text { Grade 0 } \\
\text { Mean } \pm \\
(\text { S.D) }\end{array}$ & $\begin{array}{l}\text { Grade 1 } \\
\text { Mean } \\
\text { (S.D) }\end{array}$ & $\begin{array}{l}\text { Grade II } \\
\text { Mean } \\
\text { (S.D) }\end{array}$ & $\begin{array}{l}\text { Grade III } \\
\text { Mean } \\
\text { (S.D) }\end{array}$ & F value & P Value \\
\hline Males & $\begin{array}{l}27.23 \\
8.40\end{array}$ & \pm & 25.14 \\
7.84 & \pm & $\begin{array}{l}28.33 \\
6.43\end{array}$ & \pm & - & 0.323 & $\begin{array}{l}0.725 \\
(\mathrm{~N} . S)\end{array}$ \\
\hline Females & $\begin{array}{l}20.35 \\
4.17\end{array}$ & $\begin{array}{l}23.40 \pm \\
0.00\end{array}$ & - & - & 0.356 & $\begin{array}{l}0.657 \\
(\mathrm{~N} . \mathrm{S})\end{array}$ \\
\hline Total & $\begin{array}{l}26.86 \\
8.35\end{array}$ & $\begin{array}{l}24.97 \pm \\
7.41\end{array}$ & $\begin{array}{l}28.33 \pm \\
6.43\end{array}$ & - & 0.328 & $\begin{array}{l}0.722 \\
(\mathrm{~N} . \mathrm{S})\end{array}$ \\
\hline
\end{tabular}

Table 3: Comparison of mean values of Homocystine ( $\mu \mathrm{mol} / \mathrm{lts})$ with pathological grading of OSMF.

The mean Serum Homocysteine level among males in grade 0 was $27.23 \mu \mathrm{mol} / \mathrm{lts} \pm 8.40)$, in grade I $25.14( \pm 7.84)$, in grade II 28.33 $( \pm 6.43)$. Among females the mean value of homocysteine in grade 0 was $20.35( \pm 4.17)$, in grade I $23.40 \mu \mathrm{mol} / \mathrm{lts} \pm 0.00$ ) (Table 3 ).

\begin{tabular}{|l|l|l|l|l|}
\hline Gender & $\begin{array}{l}\text { Clinical Staging } \\
\text { (Mean in } \boldsymbol{\mu m o l} / \mathbf{l i t})\end{array}$ & $\begin{array}{l}\text { Pathological Grading } \\
\text { (Mean } \boldsymbol{\mu m o l} / \mathbf{l i t})\end{array}$ & $\begin{array}{l}\text { F- } \\
\text { value }\end{array}$ & P-value \\
\hline Males & 28.6 & 26.9 & 49.34 & $\begin{array}{l}0.09 \\
\text { (N.S) }\end{array}$ \\
\hline Females & 21.9 & 21.87 & & \\
\hline F-value & 1.07 & & & \\
\hline P-value & 0.49 (N.S) & & \\
\hline
\end{tabular}

Table 4: Comparison of homocysteine level between clinical staging and pathological grading of OSMF.

The mean value of Homocysteine was compared with differentpathological grades of Oral sub-mucous fibrosis was found to be statistically no significant difference exist between pathological grading of OSMF (Table 4).

The comparison of mean value of Homocysteine between clinical stages in males was $28.6 \mu \mathrm{mol} / \mathrm{lit}$ and in females was $21.9 \mu \mathrm{mol} / \mathrm{lit} \&$ was found to be not statistically significant suggestive of homocysteine level remains constant irrespective of clinical stages \& pathological grades and gender.

\section{Discussion}

\section{Mean serum homocysteine level in OSMF patients}

The mean value of serum Homocysteine found in males was 26.9 $\mu \mathrm{mol} / \mathrm{lts}( \pm 8.1)$ female was $21.4 \mu \mathrm{mol} / \mathrm{lts}( \pm 3.4)$ \& total $24.1 \mu \mathrm{mol} / \mathrm{lts}$ $( \pm 3.3)$ which showed that higher level of serum homocysteine found in OSMF patients and males had higher value than females.

Chronic inflammation produces oxidative stress which will lead to hyperhomocysteinemia via regulation of nuclear factor kappa light chain enhancer of activated B-cells transcription factor. Increased levels of hyperhomocysteinemia exert its detrimental effects through induction of acute and chronic inflammation pathway such as endothelial adhesion, leukocyte adhesion.

\section{Comparison of mean values of homocysteine ( $\mu \mathrm{mol} / \mathrm{lts})$ with clinical staging of OSMF}

The mean value of Homocysteine in stage II among males was 25.88 $\mu \mathrm{mol} / \mathrm{lts}( \pm 7.84)$, in stage III $26.98( \pm 8.67)$, in stage IV $32.93 \pm(5.41)$. Among females the mean value of homocysteine in stage II was 20.35 $( \pm 4.17)$, in stage IV $23.40 \mu \mathrm{mol} / \mathrm{lts}( \pm 0.00)$.

The mean serum Homocysteine was compared with different clinical stages of Oral submucous fibrosis found to be statistically no significant difference exist among clinical stages of OSMF.

Serum homocysteine level does not vary with the clinical stages of laryngeal pre-cancers and Oral cancer patients; this is in accordance with Anna Eleftheriadou et al (2006) [3].

\section{Comparison of mean values of homocysteine ( $\mu \mathrm{mol} / \mathrm{lts})$ with pathological grading of OSMF}

The mean Serum Homocysteine level among males in grade 0 was $27.23 \mu \mathrm{mol} / \mathrm{lts}( \pm 8.40)$, in grade I $25.14( \pm 7.84)$, in grade II 28.33 $( \pm 6.43)$. Among females the mean value of homocysteine in grade 0 was $20.35( \pm 4.17)$, in grade I $23.40 \mu \mathrm{mol} / \mathrm{lts}( \pm 0.00)$.

The mean value of Homocysteine was compared with differentpathological grades of Oral sub-mucous fibrosis was found to be statistically no significant difference exist between pathological grading of OSMF.

Serum homocysteine level does not vary with pathological grades of OSMF and it will remain constant throughout the disease. This in accordance with Eleftheriadou et al (2006) [3] who carried out a research in laryngeal pre-cancer and oral cancer indicative of 
Page 3 of 3

pathological grading is not a diagnostic marker to assess the level of Homocysteine among different grades.

The mean homocysteine level among different clinical stages was $28.6 \mu \mathrm{mol} / \mathrm{lts}$ in males and $21.9 \mu \mathrm{mol} / \mathrm{lts}$ in females and pathological grading was $26.9 \mu \mathrm{mol} / \mathrm{lts}$ and $21.87 \mu \mathrm{mol} / \mathrm{lts}$ in males \& females respectively. Comparing the mean Homocysteine level among all the clinical stages and pathological grades in males and females was found to be statistically no significant difference exist. The Serum Homocysteine level remained constant throughout the course of the OSMF disease. The level does not vary as the clinical staging and pathological grading advances. This is in accordance with Eleftheriadou et al (2006) [3] who carried out a research in laryngeal pre-cancer and oral cancer.

\section{Conclusion}

In our study the serum Homocysteine levels in OSMF was increased than the normal threshold level. (5.32-16.50 $\mu \mathrm{mol} / \mathrm{lts}$.)

The mean value of serum Homocysteine found in males was 26.9 $\mu \mathrm{mol} / \mathrm{lts}( \pm 8.1)$ female was $21.4 \mu \mathrm{mol} / \mathrm{lts}( \pm 3.4)$ \& total $24.1 \mu \mathrm{mol} / \mathrm{lts}$ $( \pm 3.3)$ which showed that higher level of serum homocysteine found in OSMF patients and males had higher value than females.

Mean Homocysteine level gradually increased from stage II to stage IV among males and females (p-value was 0.276 and 0.657 among males and females respectively which was found to be not significant) indicating that clinical progression is directly related to level of Homocysteine as the clinical stage of disease advances.

The mean Serum Homocysteine level among males in grade 0 was $27.23 \mu \mathrm{mol} / \mathrm{lts}( \pm 8.40)$, in grade I $25.14( \pm 7.84)$, in grade II $28.33( \pm 6.43)$. Among females the mean value of homocysteine in grade 0 was $20.35( \pm 4.17)$, in grade I $23.40 \mu \mathrm{mol} / \mathrm{lts}( \pm 0.00)$.
The mean value of Homocysteine was compared with differentpathological grades of Oral sub-mucous fibrosis was found to be statistically no significant difference exist between pathological grading of OSMF.

Oral sub-mucous fibrosis "an high-risk potentially malignant condition of the oral cavity carries risk of transition to oral cancer and cause for mortality and morbidity" is a chronic inflammatory disease which is caused by micro trauma produced by friction of coarse fibers of areca nut facilitating diffusion of alkaloids into the sub epithelial connective tissue resulting in juxtraepithellial inflammatory cell infiltration(causes muscle spasm leading to fibrosis and reduced mouth opening) resulting in oxidative stress which leads to hyperhomocysteinemia and exerts its detrimental effects through induction of acute and chronic inflammation pathway such as endothelial adhesion and leukocyte adhesion, via the regulation of nuclear factor kappa light chain enhancer of activated B-cells transcription factor.

We conclude that serum homocysteine can be used as a therapeutic prognosticator marker for evaluating the outcome of treatment in the OSMF patients.

\section{References}

1. 1. Lee JJ, Hung HC, Cheng SJ, Chen YJ, Chiang CP, et al. (2006) Carcinoma and dysplasia in oral leukoplakias in Taiwan: prevalence and risk factors. Oral Surg Oral Med Oral Pathol Oral Radiol Endod 101: 472-480.

2. 2. AlinaAtif, Muhammad Atif, Tauheed S, Aamir I, Majeed F, et al. (2008) Serum Homocysteine Concentrations in Patients with hypertension. Pak J Physiology 4.

3. 3. Eleftheriadou A, Chalastras T, Ferekidou E, Yiotakis I, Kyriou L, et al. (2006) Association between squamous cell carcinoma of the head and neck and serum folate and homocysteine. Anticancer Res 26: 2345-2348. 